\title{
Acclimation of Biogenic Volatile Organic Compound Emission From Subarctic Heath Under Long-Term Moderate Warming
}

Tang, Jing; Valolahti, Hanna Maritta; Kivimäenpää, M.; Michelsen, Anders; Rinnan, Riikka

Published in:

Journal of Geophysical Research: Biogeosciences

DOI:

10.1002/2017JG004139

Publication date:

2018

Document version

Publisher's PDF, also known as Version of record

Citation for published version (APA):

Tang, J., Valolahti, H. M., Kivimäenpää, M., Michelsen, A., \& Rinnan, R. (2018). Acclimation of Biogenic Volatile Organic Compound Emission From Subarctic Heath Under Long-Term Moderate Warming. Journal of Geophysical Research: Biogeosciences, 123(1), 95-105. https://doi.org/10.1002/2017JG004139 


\section{Journal of Geophysical Research: Biogeosciences}

\section{RESEARCH ARTICLE \\ 10.1002/2017JG004139 \\ J. Tang and H. Valolahti contributed equally to this work. \\ Acclimation of Biogenic Volatile Organic Compound Emission From Subarctic Heath Under Long-Term Moderate Warming}

Key Points:

- BVOC emissions have acclimated to moderate warming after 3 years

- Stronger increase in $\mathrm{BVOC}$ than $\mathrm{CO}_{2}$ fluxes in response to warming

- Increase in BVOC emissions as a result of increased biomass and altered composition of vegetation

Supporting Information:

- Supporting Information S1

Correspondence to:

R. Rinnan,

riikkar@bio.ku.dk

Citation:

Tang, J., Valolahti, H., Kivimäenpää, M., Michelsen, A., \& Rinnan, R. (2018). Acclimation of biogenic volatile organic compound emission from subarctic heath under long-term moderate warming. Journal of Geophysical Research: Biogeosciences, 123, 95-105. https://doi.org/10.1002/2017JG004139

Received 15 SEP 2017 Accepted 5 DEC 2017

Accepted article online 12 DEC 2017 Published online 12 JAN 2018

(c)2017. American Geophysical Union. All Rights Reserved.

\author{
J. Tang ${ }^{1,2} \mathbb{D}$, H. Valolahti ${ }^{1,2}$, M. Kivimäenpää ${ }^{\mathbb{D}}$, A. Michelsen ${ }^{1,2} \mathbb{D}$, and R. Rinnan ${ }^{1,2} \mathbb{E}$ \\ ${ }^{1}$ Terrestrial Ecology Section, Department of Biology, University of Copenhagen, Copenhagen, Denmark, ${ }^{2}$ Center for \\ Permafrost (CENPERM), Department of Geosciences and Natural Resource Management, University of Copenhagen, \\ Copenhagen, Denmark, ${ }^{3}$ Department of Environmental and Biological Sciences, University of Eastern Finland, Kuopio, Finland
}

Abstract Biogenic volatile organic compound (BVOC) emissions from subarctic ecosystems have shown to increase drastically in response to a long-term temperature increase of only $2^{\circ} \mathrm{C}$. We assessed whether this increase takes place already after 3 years of warming and how the increase changes over time. To test this, we measured $\mathrm{BVOC}$ emissions and $\mathrm{CO}_{2}$ fluxes in a field experiment on a subarctic wet heath, where ecosystem plots were subjected to passive warming by open top chambers for 3 (OTC3) or 13 years (OTC13) or were kept as unmanipulated controls. Already after 3 years of moderate temperature increase of $1-2^{\circ} \mathrm{C}$, warming increased the emissions of isoprene (five- to sixfold) and monoterpenes (three- to fourfold) from the subarctic heath. The several-fold higher BVOC emissions in the warmed plots are likely a result of increased vegetation biomass and altered vegetation composition as a shift in the species coverage was observed already after 3 years of warming. Warming also increased gross ecosystem production and ecosystem respiration, but the increases were much lower than those for BVOCs. Our results demonstrate that the strong $\mathrm{BVOC}$ responses to warming already appeared after 3 years, and the $\mathrm{BVOC}$ and $\mathrm{CO}_{2}$ fluxes had acclimated to this warming after 3 years, showing no differences with another 10 years of warming. This finding has important implications for predicting $\mathrm{CO}_{2}$ and $\mathrm{BVOC}$ fluxes in subarctic ecosystems.

\section{Introduction}

Biogenic volatile organic compounds (BVOCs) are a diverse group of carbon-based compounds released not only from plants but also from soil (Peñuelas et al., 2014). Many of them (e.g., isoprenoids) are very reactive in the atmosphere, and thus, they play a significant role in tropospheric chemistry (Kulmala et al., 2004; Paasonen et al., 2013). In the atmosphere, BVOCs get rapidly photooxidized with $\mathrm{NO}_{x}$, forming harmful tropospheric ozone (Atkinson, 2000; Laothawornkitkul et al., 2009). In areas where $\mathrm{NO}_{x}$ levels are low due to the limited anthropogenic influence, for example, remote Arctic areas, BVOCs react with hydroxyl radicals and therefore deplete the oxidation capacity in the atmosphere, which leads to increase in lifetime of methane, an important greenhouse gas (Di Carlo et al., 2004). Furthermore, some BVOCs can act as precursors for secondary organic aerosols (SOAs) that scatter solar radiation and can function as cloud condensation nuclei, increasing cloudiness (Claeys et al., 2004; Scott et al., 2014). The effects of BVOCs on SOA formation and negative climatic feedback (cooling) are strongest in the northern, remote areas (Paasonen et al., 2013).

The latest estimate of annual global BVOC emissions is $760 \mathrm{Tg} C$, of which isoprene $\left(\mathrm{C}_{5} \mathrm{H}_{8}\right)$ accounts for $70 \%$ and monoterpenes for $11 \%$ (Sindelarova et al., 2014). Production and emission of isoprene is light and temperature dependent (Sharkey \& Yeh, 2001). Monoterpenes show light and temperature dependency for species lacking storage structures (Staudt \& Bertin, 1998), while BVOCs in general follow an exponential temperature dependency (Kesselmeier \& Staudt, 1999). With the conservative prediction of global temperature increase of $2^{\circ} \mathrm{C}$ by 2100 (IPCC, 2013), the annual load of $C$ to the atmosphere due to BVOCs is thus expected to rise. In subarctic and Arctic regions, the rate of increase in air temperature is predicted to be as much as twice the global average (IPCC, 2013), and this highlights the importance of gaining knowledge about BVOCs emitted from plant communities in these regions. Northern ecosystems from subarctic/Arctic wetlands (Faubert, Tiiva, Rinnan, Räsänen, et al., 2010; Holst et al., 2010) to heath tundra (Faubert, Tiiva, Rinnan, Michelsen, et al., 2010; Potosnak et al., 2013; Schollert et al., 2014; Tiiva et al., 2008) have shown significant BVOC emissions. The field experiments mimicking warmer climate have shown a great potential of increase in BVOC emissions from these ecosystems in response to different time spans of moderate 
warming (Faubert, Tiiva, Rinnan, Michelsen, et al., 2010; Kramshøj et al., 2016; Lindwall, Schollert, et al., 2016; Lindwall, Svendsen, et al., 2016; Tiiva et al., 2008; Valolahti et al., 2015).

Previous studies have shown that several plant physiological responses can acclimate to higher temperatures. The temperature optimum of photosynthesis was shown to increase under warming by $2-4^{\circ} \mathrm{C}$, but photosynthesis at the temperature optimum did not increase (Gunderson et al., 2010). Leaves can acclimate to warming by downregulating respiration rate (Slot \& Kitajima, 2015). The emission of isoprene, directly dependent on carbon availability, was lower at higher temperature, when photosynthesis and respiration showed downward acclimation (Fares et al., 2011).

Acclimation also takes place at ecosystem level: respiration is stimulated by warming after the first few years, but it stabilizes after a longer time in the new temperature regime (Rustad et al., 2001). The same acclimation of ecosystem $\mathrm{CO}_{2}$ fluxes to decadal warmer and drier conditions has also been observed in Alaskan Arctic (Oechel et al., 2000). However, it is not known yet if BVOC emissions from Arctic ecosystems can also stabilize in warmer climate since the first measurements in most long-term warming experiments have been done 6-7 years after the setup (Faubert, Tiiva, Rinnan, Michelsen, et al., 2010; Kramshøj et al., 2016; Lindwall et al., 2015; Tiiva et al., 2008). However, results from a leaf-level study of warming effects on BVOC emission from the subarctic and Arctic plants by Schollert et al. (2015) suggest that acclimation may take place: they found that the unaltered emissions in the warming treatment could be partly explained by leaf anatomical acclimations.

In addition to affecting plant metabolism and physiology, warming can also contribute to changes of vegetation composition. In the Arctic, warming increases total plant biomass by promoting especially the growth of taller and deciduous shrub species (Wahren et al., 2005; Walker et al., 2006), while the shading caused by these taller plants diminishes the coverage of ground-level plants, such as lichens and mosses (Elmendorf et al., 2012; Walker et al., 2006). Additionally, studies conducted in tundra and alpine ecosystems (Chapin et al., 2005; Gottfried et al., 2012; Henry \& Molau, 1997; Truong, Palme, \& Felber, 2007) have demonstrated that changes in species abundance can occur already after a few years of elevated temperature. Our earlier study by Valolahti et al. (2015) showed that vegetation change in response to 13 years of warming partially explained the increased BVOC emissions.

The aims of this study were to reveal if (1) experimental warming for only 3 years increases BVOC emission from a subarctic heath; (2) if shifts in vegetation composition, shown to affect BVOC emissions after 13 years of warming (Valolahti et al., 2015), already occur after warming for a few growing seasons; and (3) whether warming still continues to increase BVOC emissions rates over decadal time span or if the emission of BVOCs stabilizes or diminishes over time. In order to assess the impacts of warming on general ecosystem functioning, we also measured net ecosystem exchange (NEE) and ecosystem respiration $\left(E_{\mathrm{R}}\right)$. That also allowed us to evaluate if these processes stabilize under long-term warming, as reported for ecosystem respiration (Rustad et al., 2001) and summertime $\mathrm{CO}_{2}$ fluxes (Oechel et al., 2000).

\section{Materials and Methods}

\subsection{Study and Experimental Design}

The experimental site was located on a wet subarctic heath in Abisko, Northern Sweden $\left(68^{\circ} 21^{\prime} \mathrm{N}, 18^{\circ} 49^{\prime} \mathrm{E}\right.$, $385 \mathrm{~m}$ above sea level), where the long-term warming treatment has been maintained since 1999. Mean annual temperature in the area is around $0^{\circ} \mathrm{C}$, and precipitation is $332 \mathrm{~mm}$ (2002-2011; Callaghan et al., 2013). Vegetation at the experimental site is dominated by different low shrub species, graminoids, horsetails, and mosses (Tiiva et al., 2008; Valolahti et al., 2015). Soil characteristics have been presented in detail by Rinnan, Michelsen, and Jonasson (2008). The new short-term warming treatment was established in 2009. The new plots were selected randomly within each block of the experiment. The aim was to assess differences between unmanipulated control (C), open-top chamber summer warming for 3 years (OTC3), and OTC warming for 13 years (OTC13) treatments. Both warming treatments covered an area of $1.2 \times 1.2 \mathrm{~m}$ and used open-top warming tents made of transparent $0.05 \mathrm{~mm}$ thick polythene sheet, while the control plots were of the same size but without tents. Each treatment was replicated in six blocks yielding all in all 18 plots within an area of $1,000 \mathrm{~m}^{2}$. The responses of the OTC13 warming and interactions with litter addition have been earlier presented by Valolahti et al. (2015). 


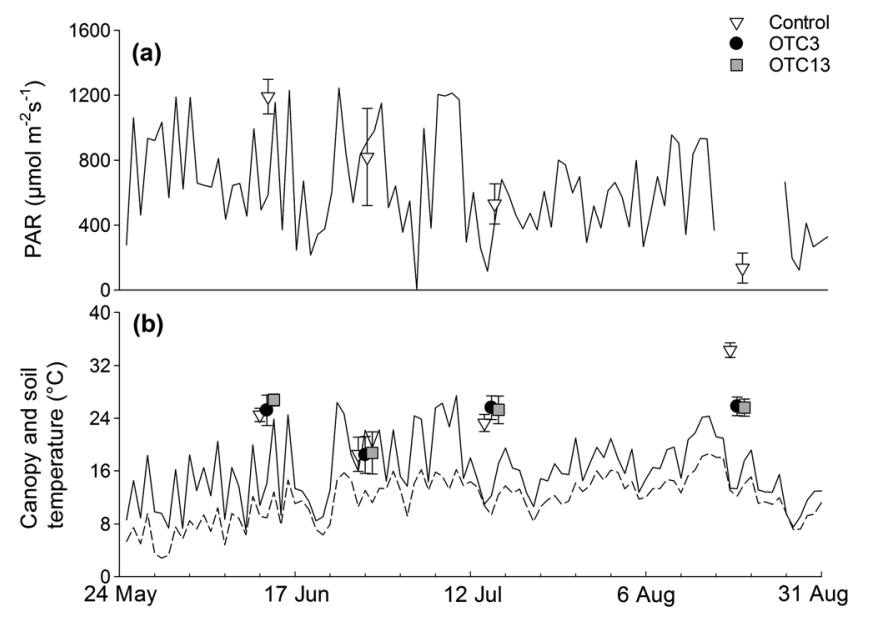

Figure 1. (a) Photosynthetically active radiation (PAR) and (b) canopy-level air (solid line) and soil (dashed line, $2 \mathrm{~cm}$ depth) temperatures between 9 a.m. and 5 p.m. (corresponding to hours when BVOC collections were made) from 24 May to 31 August in 2012. PAR data were provided by Abisko Scientific Research Station and were missing from 16 August to 24 August due to a sensor error. The symbols show averages values (SEM, $n=6$ ) measured in the flux chambers in the study plots during the BVOC collections.

\begin{abstract}
Canopy-level air temperature inside the BVOC measurement chamber was recorded (Hygrochron DS 1923-F5 iButton, Maxim Integrated Products Inc., CA, USA) once per minute during the sampling. Photosynthetically active radiation (PAR) was monitored using PAR sensors (S-LIA-M003, Onset Computer Corporation, Bourne, MA, USA) coupled to a Hobo Micro Station (Onset Computer Corporation). During the BVOC sampling, air temperature inside the flux measurement chambers did not differ more than $0.4^{\circ} \mathrm{C}$ between control (growing season average $25.4 \pm 1.4^{\circ} \mathrm{C}$ ), OTC3 $\left(25.8 \pm 1.4^{\circ} \mathrm{C}\right.$ ), and OTC13 $\left(25.6 \pm 1.3^{\circ} \mathrm{C}\right)$. In the long term, the OTCs increase the canopy air temperature by $0.8^{\circ} \mathrm{C}$ and the soil temperature at $2 \mathrm{~cm}$ depth by $0.7^{\circ} \mathrm{C}$ (Ravn et al., 2017). The OTCs decreased PAR, on average by $16 \%$ (data not shown). PAR, canopy-level air temperature, and soil temperature during the measurement period are shown in Figure 1.
\end{abstract}

\subsection{Vegetation Analysis}

Vegetation coverage and species composition were analyzed once during the season, on 10-11 August 2012. The point intercept method described by Jonasson (1988) was used, and the vegetation analyses were made for $0.22 \times 0.22 \mathrm{~m}$ plots subjected to gas exchange measurements. Plant species were grouped as graminoids, forbs, deciduous shrubs, evergreen shrubs, vascular cryptogams, mosses, and lichens. In addition, the coverage of litter and standing dead biomass was recorded.

\subsection{Sampling of BVOCs}

Sampling was done 4 times during the growing season in 2012 (Figure 1) using transparent polycarbonate chambers (thickness 0.0015 m, $0.22 \times 0.22$ m, height 0.2 m; Vink Finland, Kerava, Finland). Chambers were placed on aluminum collars, which had been permanently installed in the plots in the beginning of the experiment. To create an airtight headspace, collar grooves were filled with water before placing the chamber. The air was circulated through the chambers using battery-operated pumps (12 V; Rietschle Thomas, Puchheim, Germany) at $200 \mathrm{~mL} \mathrm{~min}^{-1}$ for both inflow and outflow, and the chambers were equipped with fans to ensure well-mixed headspace. The incoming air was purified using a charcoal filter (Wilkerson F03C2-100) to remove particles and volatile impurities and a $\mathrm{MnO}_{2}$ scrubber to remove ozone (Ortega \& Helmig, 2008).

During each sampling time, two blank samples were collected to identify BVOCs emitted from the sampling and analysis equipment following Lindwall, Svendsen, et al. (2016), and the low amount of VOCs in blanks was removed from the data set.

Before sampling, the ambient air inside the chamber was replaced with filtered air by flushing for 10 min with

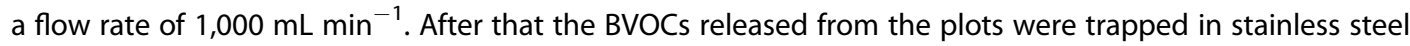
adsorbent tubes (150 mg Tenax TA, $200 \mathrm{mg}$ Carbograph 1TD, Markes International Limited, Llantrisant, UK) for $30 \mathrm{~min}$. The tubes were sealed with Teflon-coated brass caps and stored at $5^{\circ} \mathrm{C}$ to prevent fragmentation of collected BVOCs before analysis within 2 weeks from sampling.

\subsection{GC-MS Analysis of BVOCs}

BVOCs collected in adsorbent tubes were analyzed using a Unity 2 thermal desorber (Markes International Limited, Llantrisant, UK) coupled with an Ultra autosampler and a gas chromatograph-mass spectrometer (7890A Series GC, 5975C inert MSD/DS Performance Turbo El, Agilent Technologies, Santa Clara, CA, USA). After thermodesorption at $250^{\circ} \mathrm{C}$ for $10 \mathrm{~min}$ and cryofocusing at $-10^{\circ} \mathrm{C}$, the samples were immediately injected, with helium as a carrier gas, into an HP-5 capillary column for separation (length $50 \mathrm{~m} \times$ diameter $0.2 \mathrm{~mm} \times 0.33 \mu \mathrm{m}$ film thickness). The oven temperature during the first minute was $40^{\circ} \mathrm{C}$, then it was raised to $210^{\circ} \mathrm{C}$ at a rate of $5^{\circ} \mathrm{C} \mathrm{min}{ }^{-1}$ and then further to $250^{\circ} \mathrm{C}$ at a rate of $20^{\circ} \mathrm{C} \mathrm{min}^{-1}$. 
Table 1

Coverage of Plant Functional Groups (\% Cover) on 10-11 August (Mean \pm SEM, $n=6$ ) in Control, Open Top Chamber Warming for 3 (OTC3) and 13 Years (OTC13) and the Statistical Significance for Differences Among Treatments (ANOVA)

\begin{tabular}{lcccc}
\hline & Control & OTC3 & OTC13 & $P$-value \\
\hline Graminoids & $24.7 \pm 4.8$ & $15.3 \pm 4.6$ & $24.7 \pm 6.4$ & 0.361 \\
Forbs & $5.2 \pm 1.4$ & $10.7 \pm 4.2$ & $14.5 \pm 8.4$ & 0.604 \\
Deciduous shrubs & $26.2 \pm 4.7$ & $32.0 \pm 8.2$ & $32.7 \pm 13.7$ & 0.943 \\
Evergreen shrubs & $47.0 \pm 10.1$ & $53.3 \pm 10.0$ & $57.2 \pm 9.3$ & 0.650 \\
Vascular cryptogams & $4.5 \pm 2.6^{\mathrm{a}}$ & $16.8 \pm 3.9$ & $6.3 \pm 3.3$ & 0.042 \\
Total vascular plants & $107.5 \pm 12.5$ & $128.2 \pm 16.1$ & $135.3 \pm 20.1$ & 0.061 \\
Mosses & $8.3 \pm 4.6$ & $18.7 \pm 3.7$ & $10.3 \pm 4.3$ & 0.218 \\
Lichens & $7.5 \pm 4.5$ & $0.7 \pm 0.7$ & $3.5 \pm 2.6$ & 0.183 \\
Litter & $15.5 \pm 1.9$ & $13.8 \pm 2.9$ & $16.0 \pm 3.5$ & 0.832 \\
Standing dead & $9.7 \pm 1.5$ & $11.8 \pm 2.2$ & $10.3 \pm 2.8$ & 0.787 \\
\hline
\end{tabular}

Note. Values followed by different superscript letters within a functional group significantly differ from each other based on the pairwise multiple comparisons.
BVOCs were identified using pure standards and according to their mass spectra compared with the NIST library. They were quantified by pure standard solutions for isoprene, $\alpha$-pinene, camphene, sabinene, 3 -carene, limonene, 1,8-cineole, $\gamma$-terpinene, copaene, $\delta$-cadinene, aromadendrene, and cis-3-hexenyl acetate (Fluka, Buchs, Switzerland). When quantifying compounds for which no pure standard was available, $\alpha$-pinene was used for quantification of monoterpenes, copaene for sesquiterpenes, and cis-3-hexenyl acetate for other volatile organic compounds detected. Chromatograms were analyzed using the software Enhanced ChemStation (Agilent Technologies, Santa Clara, CA, USA). Compounds that had an identification quality above $90 \%$ in the NIST data library and were present at least in $10 \%$ of the samples were accepted in the data set (Faubert, Tiiva, Rinnan, Michelsen, et al., 2010). BVOC emission rates were expressed on ground area basis $\left(\mu \mathrm{g} \mathrm{m}^{-2} \mathrm{~h}^{-1}\right)$ (see Faubert et al. (2012) for description of calculations) with chamber headspace volume corrected for microtopographical differences.

\subsection{Measurement of $\mathrm{CO}_{2}$ Exchange}

Ecosystem respiration $\left(E_{\mathrm{R}}\right)$ and net ecosystem exchange (NEE) were measured with an EGM-4 Environmental Gas Monitor (PP Systems, Hitching, UK) connected to an Environmental Monitor Sensor Probe Type 3 (PP Systems, Hitching, UK). A transparent polycarbonate chamber with a volume of $13.5 \mathrm{~L}$ and coupling to the EGM4 was placed in the aluminum collar groove, which was filled with water to create an airtight headspace. A fan was used to ensure the mixing of the headspace. NEE was measured continuously for 5 min, then the chamber was lifted to return to ambient $\mathrm{CO}_{2}$ concentration and $E_{\mathrm{R}}$ was measured. For the $E_{\mathrm{R}}$ measurement, the chamber was darkened and the fluxes were recorded for $5 \mathrm{~min}$. Gross ecosystem production (GEP) was calculated by summing NEE and $E_{\mathrm{R}}$. Positive fluxes indicate carbon gain by the ecosystem. After each measurement the soil temperature in each plot was measured from 3 points at 2 and $5 \mathrm{~cm}$ depth (T-Handle Lab Thermometer DT520TH), and soil moisture was measured using Theta Probe ML2x (Delta T-Devices Ltd, Cambridge, UK) (see Table S2).

\subsection{Statistics}

Mixed models analysis of variance (ANOVA) with Bonferroni post hoc test was used to analyze for treatment effects on emissions of isoprene, total monoterpenes (MTs), total sesquiterpenes (SQTs), and total other VOCs as well as for $E_{\mathrm{R}}$, GEP, and NEE (IBM SPSS Statistics 23, Armonk, NY, USA). The model included treatment (with three levels: control, OTC3, and OTC13) and date as fixed factors, their interactions, and block as a random factor. To test for the normality of the data and the model residuals, Shapiro-Wilks normality test was used and data were inspected for potential inhomogeneity of variance. Logarithmic or square root transformation was used if needed. $P$-values $<0.05$ were considered as statistically significant and those $<0.1$ to indicate marginal significance. Vegetation coverage data were tested for treatment effects using ANOVA when the presumptions of parametric tests were fulfilled and using the nonparametric Kruskall-Wallis one-way ANOVA followed by pairwise multiple comparisons, when needed.

To assess how the treatments had affected the ecosystem, data on $\mathrm{CO}_{2}$ exchange (NEE, GEP, and $\mathrm{E}_{\mathrm{R}}$ ), VOC emissions (the growing season averages), and the cover of functional groups of vegetation were subjected to a principal component analysis (PCA). The data were mean-centered and standardized to unit-variance. Partial least squares regression (PLSR) was used to analyze the influence of coverage of individual plant species on the emissions of the 10 most emitted individual BVOCs. One-component PLSR models, which were cross-validated using seven cross-validation groups, were extracted separately for each BVOC. The PCA and PLSR analyses were conducted using Simca 13.0.3 (Umetrics, Umeå, Sweden).

\section{Results}

\subsection{Vegetation Coverage}

Warming in general increased the coverage of total vascular plants by $19 \%$ after 3 years and by $26 \%$ after 13 years of exposure, although this was only marginally significant (Table 1). For functional groups 

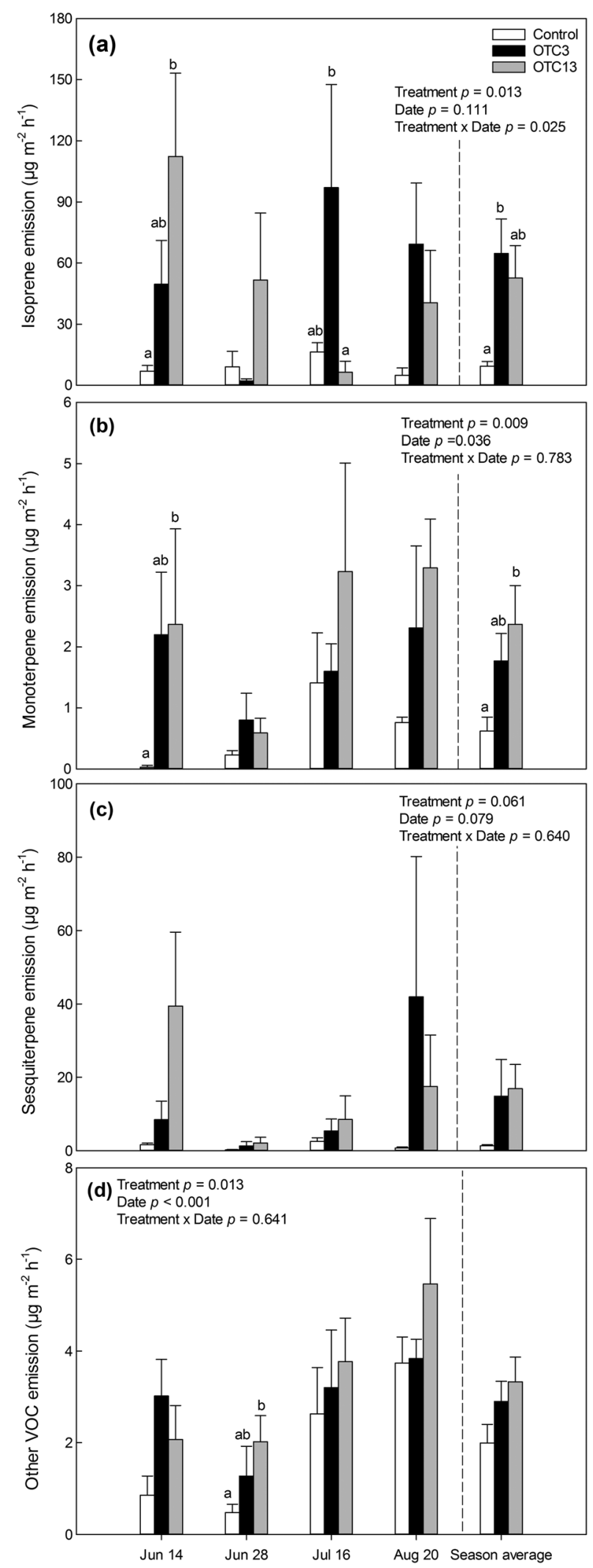

(graminoids, forbs, deciduous shrubs, evergreen shrubs, vascular cryptogams, mosses, and lichens), there were no significant treatment effects except for the coverage of vascular cryptogams, which was a factor of 2.7 higher in the OTC warming for 3 years as compared to the control.

At species level, the most abundant vascular plant species in the experimental plots were Carex vaginata, Vaccinium uliginosum, Andromeda polifolia, and Empetrum hermaphroditum (Table S1 in the supporting information). The coverage of $A$. polifolia was a factor of 2 higher in the OTC13 treatment compared to the control, while OTC3 treatment did not significantly differ from either of the other treatments. The coverage of Equisetum arvense was significantly higher in the OTC3 treatment than in the OTC13 treatment.

\subsection{BVOC Emission Rates}

A total of 31 compounds, isoprene, 7 MTs, 15 SQTs, and 8 other VOCs were detected. Isoprene was the most emitted single compound with emission rates varying from 0 to $335.7 \mu \mathrm{g} \mathrm{m}^{-2} \mathrm{~h}^{-1}$. The most emitted MT detected in this study was 1,8-cineole (maximum at $6.6 \mu \mathrm{g} \mathrm{m}^{-2} \mathrm{~h}^{-1}$ and the mean $0.9 \pm 0.2 \mu \mathrm{g} \mathrm{m}^{-2} \mathrm{~h}^{-1}$ ). The most emitted SQT was $\beta$-selinene (maximum at $105.6 \mu \mathrm{g} \mathrm{m}^{-2} \mathrm{~h}^{-1}$ and the mean $2.9 \pm 1.6 \mu \mathrm{g} \mathrm{m}^{-2} \mathrm{~h}^{-1}$ ), and for other VOCs, it was toluene (maximum at $7.5 \mu \mathrm{g} \mathrm{m}^{-2} \mathrm{~h}^{-1}$ and the mean $1.2 \pm 0.2 \mu \mathrm{g} \mathrm{m}^{-2} \mathrm{~h}^{-1}$ ). Emission rates for the individual compounds emitted on each date and averaged over the season can be found in Table S3.

Warming increased the emission rates of isoprene, MTs, and other VOCs and tended to increase SQT emission (Figure 2). For isoprene emission, the increase compared to the control in the growing season average was by a factor 6.9 for OTC 3 and by a factor of 5.6 for OTC13. In the growing season average, there was no significant difference between OTC3 and OTC13 (Figure 2a). There was a significant treatment $\times$ date interaction, as the isoprene emission rates varied differently among the treatments throughout the season. MT emissions, averaged over the season, increased under warming, and this difference was significant between control and OTC13 (Figure 2b). Emissions from OTC13 increased by a factor of 3.8 compared to control. No significant difference was found between OTC3 and OTC13. SQT emissions in general had high variations within dates and treatments. There was a marginally significant treatment effect on SQT emission rates (Figure $2 \mathrm{c}$ ). Emissions from OTC13 increased by factor of 12.7, and those from OTC3 increased by a factor of 11 , compared to control. Overall, warming tended to increase the emission rates of the other VOCs in both OTC3 and OTC13 compared to the control, but this factor 1.5- to 1.7-fold increase was not statistically significant. A significant increase in OTC13 compared to control was detected on 28 June (Figure 2d). Overall lower

Figure 2. Mean emission rates of (a) isoprene, (b) monoterpenes, (c) sesquiterpenes, and (d) other VOCs on each measurement date and averaged over the growing season. The statistical significances for the main effects and interaction for treatment and date are shown (mixed models ANOVA). The bars with different letters within a date differed significantly from each other $(p<0.05$, Bonferroni pairwise comparison). Only the days with significant treatment effects have letters. 

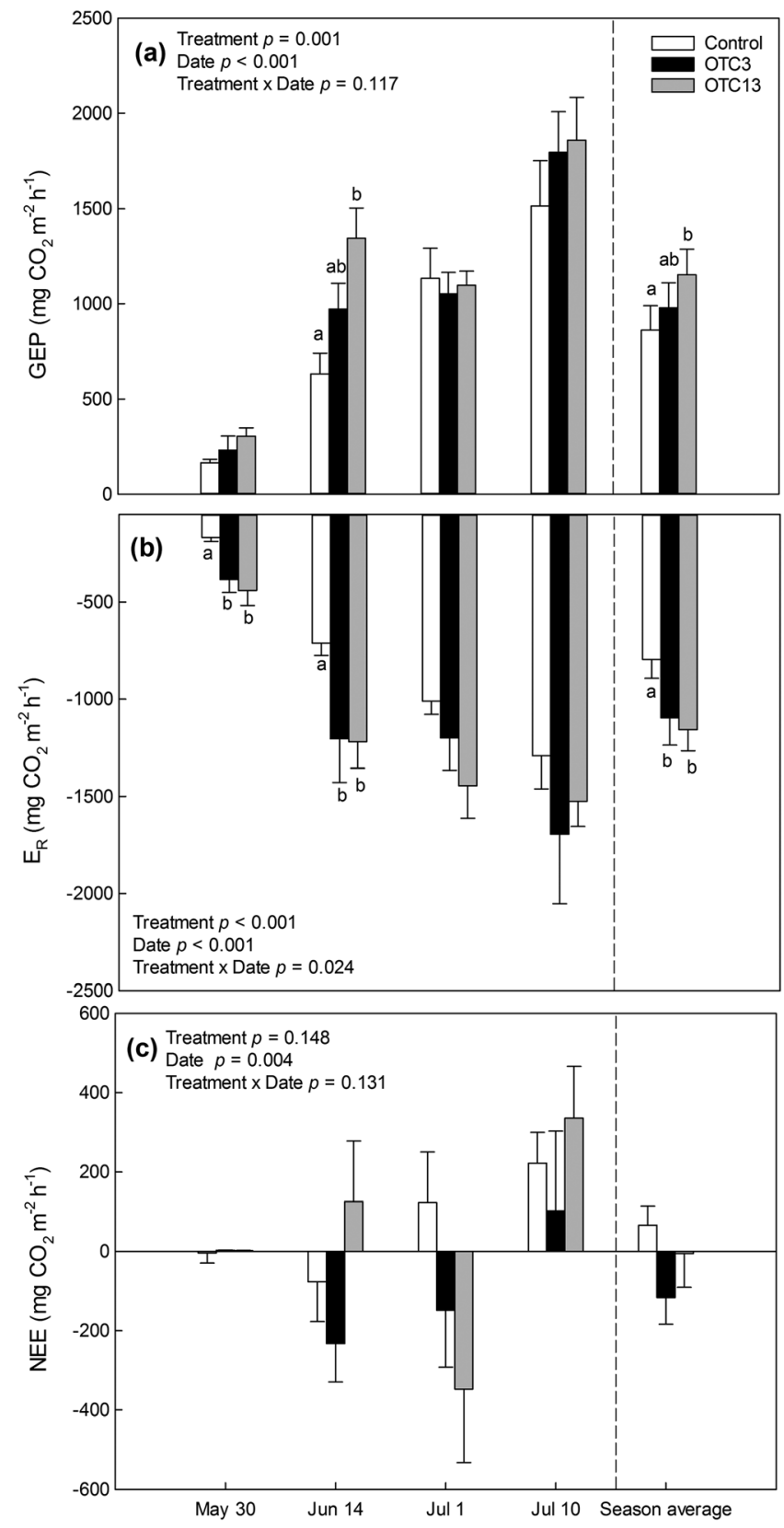

Figure 3. (a) Gross ecosystem production (GEP), (b) ecosystem respiration $\left(E_{\mathrm{R}}\right)$, and (c) net ecosystem exchange (NEE) on each date and averaged over the growing season. The statistical significances for the main effects and interaction for treatment and date are shown (mixed models ANOVA). The bars with different letters within a date differed significantly from each other ( $p<0.05$, Bonferroni pairwise comparison). Only the days with significant treatment effects have letters. emission levels were noticeable in MTs, SQTs, and other VOCs on 28 June, when temperature was lower than in other collection dates.

\section{3. $\mathrm{CO}_{2}$ Exchange}

Both GEP and $E_{\mathrm{R}}$ were significantly increased by warming. The two OTC treatments did not differ from each other (Figures $3 a$ and $3 b$ ). The difference in GEP was significant between control and OTC13, where fluxes were increased by on average $34 \%$ compared to the control. For $E_{R}$, both OTC3 and OTC13 increased the fluxes significantly compared to control, by $38 \%$ and $46 \%$, respectively. Warming did not significantly alter NEE. When averaged over the growing season, the control plots were sinks of $\mathrm{CO}_{2}$, whereas OTC3 was a net source of $\mathrm{CO}_{2}$ and the NEE in OTC13 was close to zero (Figure 3c), although these differences were not statistically significant.

\subsection{Correlations Between $\mathrm{CO}_{2}$ Exchange, VOC Emissions, and the Vegetation Coverage}

The PCA showed that based on the $\mathrm{CO}_{2}$ exchange, VOC emissions, and the vegetation coverage, the control plots differed from the OTC3 and OTC13 plots, which were similar to each other, and the warmed plots showed more between-plot variation than the controls (Figure 4a). The first two principal components explained $44 \%$ of the variance in the data.

According to the loading plot, GEP, $E_{\mathrm{R}}$ and NEE correlated positively with the emission of MT and SQT as well as with the coverage of deciduous and evergreen shrubs, vascular cryptogams, and forbs (Figure 4b). The $\mathrm{CO}_{2}$ flux variables correlated negatively with the coverage of litter, standing dead biomass and graminoids. Isoprene emission was negatively correlated with the coverage of evergreen and deciduous shrubs, forbs, and lichens and showed positive correlation with the cover of mosses and graminoids. The emission of other (nonterpenoid) VOCs was also positively correlated with isoprene emission and the coverage of mosses.

The PLSR analysis on the influence of species coverage showed that isoprene emission was positively related to the coverage of Betula nana, Carex parallela, and Salix reticulata but negatively related to the coverage of V. uliginosum, Astragalus alpinus, lichens, and E. hermaphroditum (Figure 5). The coverage of $B$. nana also positively correlated with the emissions of 1,8-cineole, $\alpha$-caryophyllene, germacrene, and $\delta$-cadinene (Figures S1 and S2 in the supporting information). The coverage of Rhododendron lapponicum positively correlated with the emission of $\beta$ selinene (Figure S2), and that of graminoids, such as C. parallela and Festuca ovina, correlated with toluene emission (Figure S3).

\section{Discussion}

Our results show that already after 3 years of air temperature increase, the OTC treatment clearly increased the BVOC emissions from the subarctic heath. The increase in BVOC emissions in response to warming would be expected because both the biosynthesis of the compounds and the diffusion of compounds from storage pools are temperature-dependent (Loreto \& Schnitzler, 2010). However, we also show that there were no differences in BVOC emissions between OTC treatments carried out for 3 and 13 years. This suggests that a relatively short-term warming exposure is enough to cause an increase and that this increase remains high over a continuous exposure of 10 additional years, without a further significant increase. 


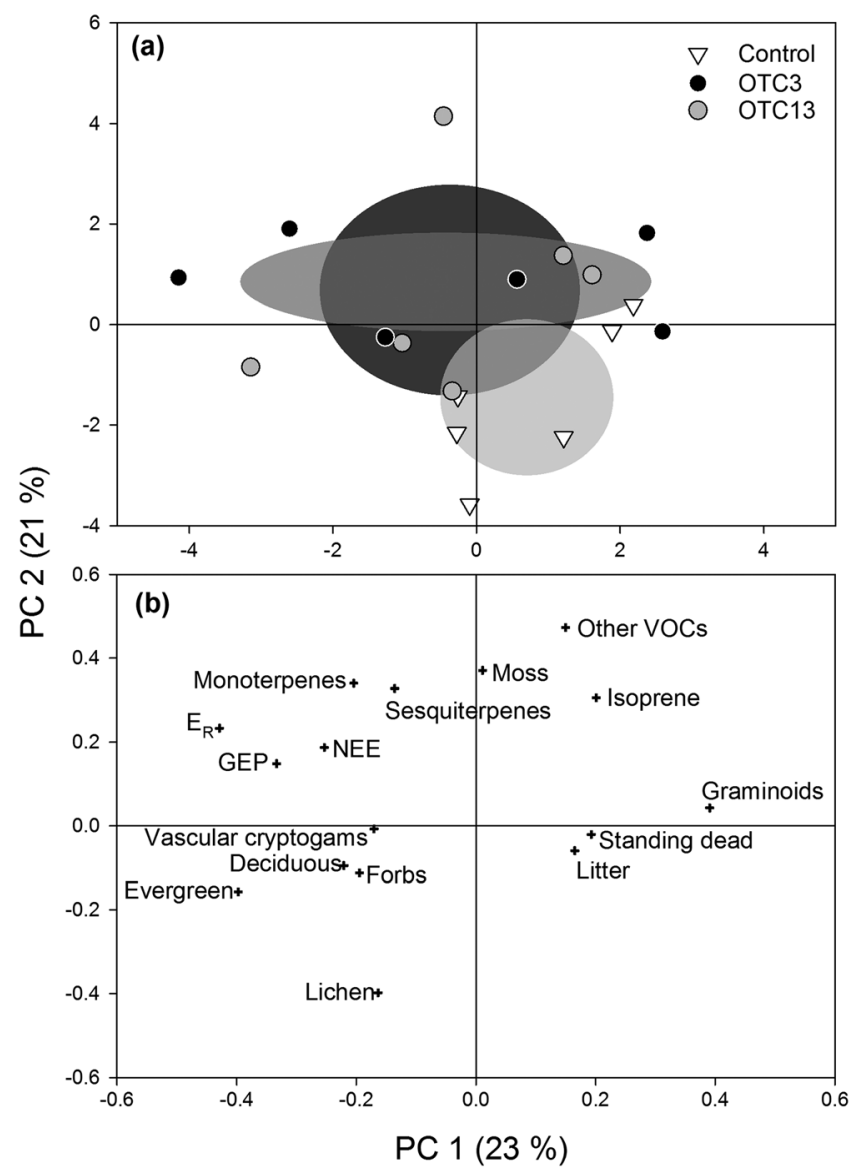

Figure 4. Principal component analysis (PCA) on the BVOC emissions (isoprene, total monoterpenes, total sesquiterpenes, and total other VOCs), $\mathrm{CO}_{2}$ fluxes (NEE, GEP, and $E_{\mathrm{R}}$ ), and coverage of plant functional groups. (a) Scores for the individual plots are shown with symbols and confidence intervals as ellipses (control, light gray; OTC3, medium gray; OTC13, dark gray) and (b) the corresponding loadings. Growing season averages were used in the analysis. The variance explained by each principal component $(\mathrm{PC})$ is shown in parentheses.
The increase in BVOC emissions, including isoprene, MTs, SQTs, and other VOCs, was well in agreement with earlier reports from the same location (Faubert, Tiiva, Rinnan, Michelsen, et al., 2010; Tiiva et al., 2008; Valolahti et al., 2015), and with the suggested high temperature dependency of subarctic BVOC emissions (Holst et al., 2010; Potosnak et al., 2013; Tang et al., 2016). In general, direct and physiological responses of BVOC emissions can occur rapidly after the plant experiences an increase in temperature, although isoprene and monoterpene production are known to acclimate to warmer conditions within days (Niinemets et al., 2010). In field experiments this effect is not as straightforward as plants can have delayed responses to warming, and/or interactions with other biotic or abiotic factors, which also influence BVOC emissions (Niinemets et al., 2010; Sharkey et al., 1999).

In the present study, the increased BVOC emissions were most likely partly a result of increased vegetation coverage and a shift in vegetation composition. The total vascular plant coverage showed an increasing trend from the control to 3 years and further to 13 years of OTC warming. An increase in the coverage of vascular cryptogams had already manifested after 3 years of OTC warming. These kinds of rapid composition shifts in Arctic plant communities caused by warming over a few growing seasons have also been observed at 11 locations across the tundra biome (Walker et al., 2006).

An increased abundance of deciduous and evergreen shrubs and forbs as observed in response to recent warming in the Arctic (Elmendorf et al., 2012) could contribute to an increase in BVOC emissions. According to the PCA on our data, the coverage of vascular cryptogams, shrubs, and forbs positively correlated with MT and SQT emissions. The drastically increased MT (three- to fourfold higher season averages compared to control) and SQT (11- to 13-fold higher season averages compared to control) emissions were probably related to increased abundances of many terpenoid emitters in both the OTC treatments. The PLSR analyses of the dependence of emission of the most emitted individual BVOCs on the plant species coverage showed more fine-scaled dependencies. Of the dominant shrubs, B. nana coverage was positively correlated with emissions of isoprene, and several of the most emitted mono- and sesquiterpenes, and B. nana is often found to increase in abundance and growth with warmer climate (Hollesen et al., 2015; Sistla et al., 2013). B. nana is not an isoprene emitter itself (Vedel-Petersen et al., 2015), and the correlation between the $B$. nana coverage and isoprene emission is likely due to the presence of co-occurring isoprene-emitting species or another factor correlating with the $B$. nana coverage. The coverage of the dwarf shrub $A$. polifolia was significantly increased in the OTC13 treatment, and this species is known as monoterpene and sesquiterpene emitter (Rinnan et al., 2005). The coverages of both A. polifolia and B. nana were positively related to the emission of SQTs such as $\delta$-cadinene. As both plant coverage and compound emission are likely to increase under warming, an altered climate will modify the blend of volatiles from tundra in a warmer climate.

The emissions of nonterpenoid VOCs were also increased by warming although not as drastically as those of terpenoids. The compounds of this group, for example, toluene, benzene, and 2-methylfuran, have been earlier reported in emissions from soil and litter (Gray et al., 2010; Huber et al., 2010; Leff \& Fierer, 2008). In our experimental setup and ecosystem plot-level measurements, we are unable to precisely identify the source of the emitted BVOCs, but the nature of these compounds and the lower temperature-dependency suggests that they could originate from soil and litter.

We also measured ecosystem $\mathrm{CO}_{2}$ fluxes in order to assess whether the impacts of warming on these follow the same trend as for the BVOC emissions. GEP and $E_{\mathrm{R}}$ increased under OTC warming, which is in agreement 


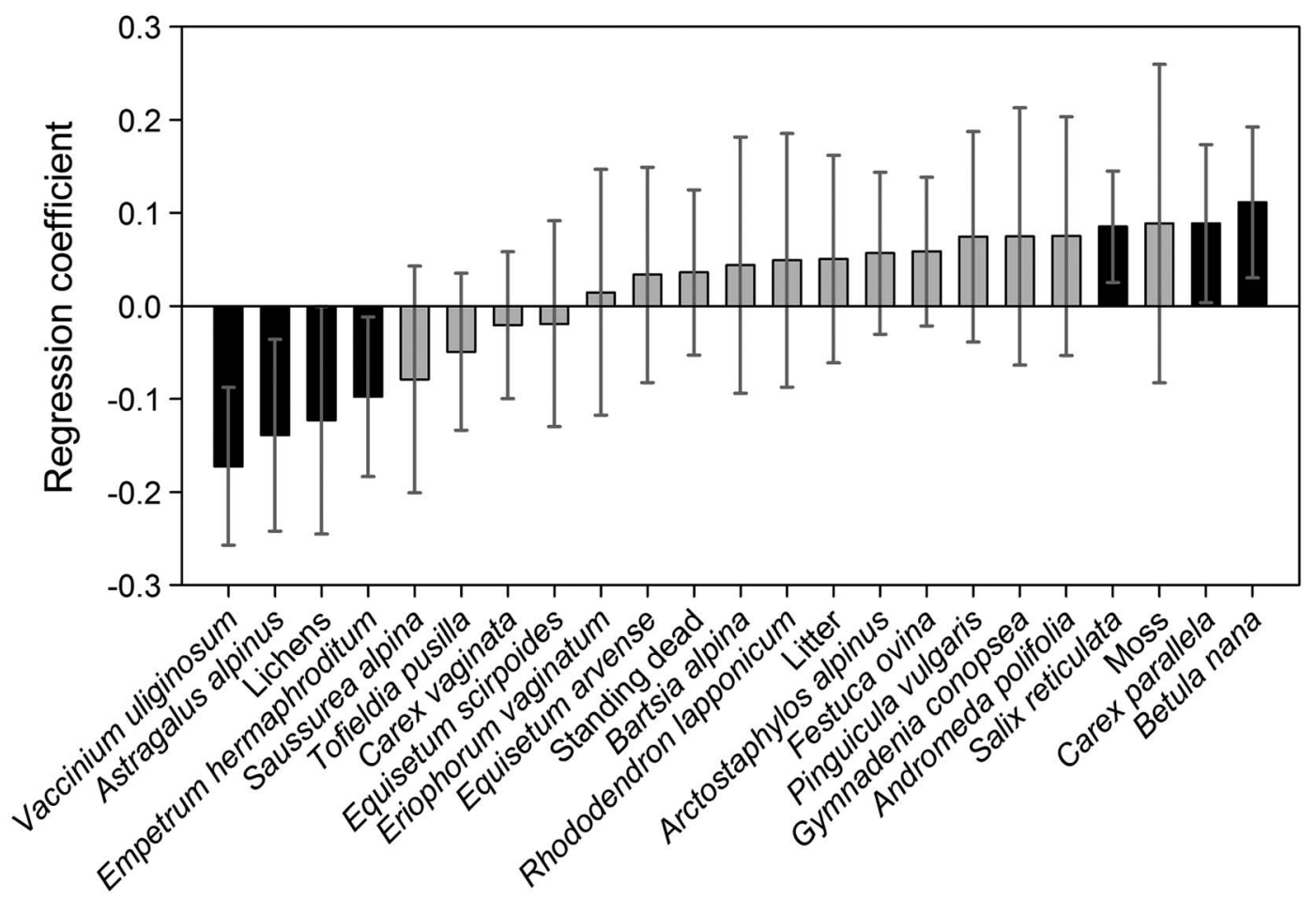

Figure 5. Regression coefficients of a partial least squares regression (PLSR) model for the covariance between plant species coverage and isoprene emission. Positive regression coefficients indicate a positive relationship and negative ones a negative relationship. The error bars show confidence intervals of the regression coefficients. Significant factors are shown in black.

with results from several North American warming experiments (Hobbie \& Chapin, 1998; Oberbauer et al., 2007; Welker et al., 2004) and a Greenlandic study (Marchand et al., 2004). GEP represents total photosynthetic carbon uptake in light by vegetation present in the measured ecosystem plots, while $E_{\mathrm{R}}$ includes both dark respiration of vegetation and $\mathrm{CO}_{2}$ released from microbial decomposition in soils. According to the PCA, GEP and $E_{\mathrm{R}}$ appear to be linked to the increased coverage of shrubs, vascular cryptogams, and forbs. Thus, similarly to $\mathrm{BVOC}$ emissions, $\mathrm{CO}_{2}$ exchange appears to be largely controlled by vegetation changes in the studied ecosystem. We suggest that part of the increased BVOC emissions may be due to the higher photosynthesis and the concomitant increased carbon allocation to BVOC synthesis under warming.

The ongoing vegetation changes also seem to override any sign of treatment effects decreasing over time, a response acclimation pattern that has been earlier shown for soil respiration in Alaskan moist/wet tundra (Oechel et al., 2000). No significant change was observed in NEE, because both GEP and $E_{\mathrm{R}}$ increased under warming and canceled out the effects on NEE. However, the magnitude of the increase in response to the moderate warming was much less for GEP and $E_{\mathrm{R}}$ than for the emissions of most BVOC groups, only up to $46 \%$ compared to an increase by a factor of 3-13. This highlights the increasing importance of accounting for the emissions of BVOCs in the Arctic.

No significant changes were observed in BVOC emissions, GEP, or $E_{\mathrm{R}}$ between 3 and 13 year long exposures to OTC warming on this subarctic heath. This suggests that after the relatively rapidly developing initial responses, which had already taken place after 3 years, the ecosystem acclimates to the new temperature regime, leading to a slower rate of change. This observed acclimation could be related not only to the physiological acclimation to the changes in growth conditions, like nutrient status or neighboring species (Oechel et al., 2000), but also to leaf anatomical adaption (Schollert et al., 2015). Our study does not allow for identification of other acclimation or adaptation responses, such as plant physiological responses to new environmental conditions or leaf anatomical changes.

In this study, the passive warming by OTCs only produced a $0.8^{\circ} \mathrm{C}$ long-term temperature increase. The predicted increase by $2^{\circ} \mathrm{C}$ by the year 2100 (IPCC, 2013) is likely to cause even larger alterations in the vegetation 
and ecosystem gas fluxes. Further, as warming continues in the Arctic, the responses observed in this study will most probably be influenced by other longer term processes, for example, more dramatic vegetation shifts (Elmendorf et al., 2012), slowing-down in decomposition of soil organic matter (thus ecosystem respiration) (Sistla et al., 2013) and changes in plant and soil C:N ratios (Oechel et al., 2000). Furthermore, the predicted increase in precipitation (mostly in winter) and drought periods in summer (AMAP, 2012) could further complicate the ecosystem responses to warmer climate. Field experiments with multiple changing climatic factors and their interactions, focusing on both short-term and long-term responses, could greatly promote the understanding of underlying processes in controlling ecosystem acclimation. Our study, a first attempt to compare short-term and long-term warming responses of $\mathrm{BVOCs}$ and $\mathrm{CO}_{2}$ fluxes, provides strong evidence of ecosystem acclimation in this subarctic ecosystem.

\section{Acknowledgments}

This work was supported by the Maj and Tor Nessling Foundation; the Danish Council for Independent Research, Natural Sciences; the Villum Foundation; and the Danish National Research Foundation (activities within the Center for Permafrost, CENPERM DNRF100). We would like to thank Jeff Bidstrup and Jacqueline M. Anderson for field assistance, Gosha Sylvester and Esben V. Nielsen for laboratory assistance, Timo Oksanen for technical assistance, and Abisko Scientific Research Station for providing an excellent logistical basis for the work. Jing Tang has received funding from the European Union's Horizon 2020 research and innovation programme under the Marie Sklodowska-Curie grant agreement 707187. Data are provided in the supporting information.

\section{References}

AMAP (2012). Arctic climate issues 2011: Changes in Arctic snow, Water, Ica and Permafrost, SWIPA 2011 Overview Report, 43, Oslo, Norway. Atkinson, R. (2000). Atmospheric chemistry of VOCs and NOx. Atmospheric Environment, 34(12), 2063-2101. https://doi.org/10.1016/ S1352-2310(99)00460-4

Callaghan, T. V., Jonasson, C., Thierfelder, T., Yang, Z., Hedenås, H., Johansson, M., ... Sloan, V. L. (2013). Ecosystem change and stability over multiple decades in the Swedish subarctic: Complex processes and multiple drivers. Philosophical Transactions of the Royal Society of London B: Biological Sciences, 368(1624). https://doi.org/10.1098/rstb.2012.0488

Chapin, F. S., Sturm, M., Serreze, M. C., McFadden, J. P., Key, J. R., Lloyd, A. H., ... Welker, J. M. (2005). Role of land-surface changes in Arctic summer warming. Science, 310(5748), 657-660. https://doi.org/10.1126/science.1117368

Claeys, M., Graham, B., Vas, G., Wang, W., Vermeylen, R., Pashynska, V., ... Maenhaut, W. (2004). Formation of secondary organic aerosols through photooxidation of isoprene. Science, 303(5661), 1173-1176. https://doi.org/10.1126/science.1092805

Di Carlo, P., Brune, W. H., Martinez, M., Harder, H., Lesher, R., Ren, X., ... Campbell, C. (2004). Missing OH reactivity in a forest: evidence for unknown reactive biogenic VOCs. Science, 304(5671), 722-725. https://doi.org/10.1126/science.1094392

Elmendorf, S. C., Henry, G. H. R., Hollister, R. D., Bjork, R. G., Boulanger-Lapointe, N., Cooper, E. J., ... Wipf, S. (2012). Plot-scale evidence of tundra vegetation change and links to recent summer warming. Nature Climate Change, 2(6), 453-457. https://doi.org/10.1038/ nclimate1465

Fares, S., Mahmood, T., Liu, S., Loreto, F., \& Centritto, M. (2011). Influence of growth temperature and measuring temperature on isoprene emission, diffusive limitations of photosynthesis and respiration in hybrid poplars. Atmospheric Environment, 45(1), 155-161. https://doi. org/10.1016/j.atmosenv.2010.09.036

Faubert, P., Tiiva, P., Michelsen, A., Rinnan, Å., Ro-Poulsen, H., \& Rinnan, R. (2012). The shift in plant species composition in a subarctic mountain birch forest floor due to climate change would modify the biogenic volatile organic compound emission profile. Plant and Soil, 352(1), 199-215. https://doi.org/10.1007/s11104-011-0989-2

Faubert, P., Tiiva, P., Rinnan, Å., Michelsen, A., Holopainen, J. K., \& Rinnan, R. (2010). Doubled volatile organic compound emissions from subarctic tundra under simulated climate warming. New Phytologist, 187(1), 199-208. https://doi.org/10.1111/ j.1469-8137.2010.03270.x

Faubert, P., Tiiva, P., Rinnan, Å., Räsänen, J., Holopainen, J. K., Holopainen, T., ... Rinnan, R. (2010). Non-methane biogenic volatile organic compound emissions from a Subarctic peatland under enhanced UV-B radiation. Ecosystems, 13(6), 860-873. https://doi.org/10.1007/ s10021-010-9362-1

Gottfried, M., Pauli, H., Futschik, A., Akhalkatsi, M., Barancok, P., Benito Alonso, J. L., ... Grabherr, G. (2012). Continent-wide response of mountain vegetation to climate change. Nature Climate Change, 2(2), 111-115. https://doi.org/10.1038/nclimate1329

Gray, C. M., Monson, R. K., \& Fierer, N. (2010). Emissions of volatile organic compounds during the decomposition of plant litter. Journal of Geophysical Research, 115, G03015. https://doi.org/10.1029/2010JG001291

Gunderson, C. A., O'Hara, K. H., Campion, C. M., Walker, A. V., \& Edwards, N. T. (2010). Thermal plasticity of photosynthesis: The role of acclimation in forest responses to a warming climate. Global Change Biology, 16(8), 2272-2286. https://doi.org/10.1111/ j.1365-2486.2009.02090.x

Henry, G. H. R., \& Molau, U. (1997). Tundra plants and climate change: the International Tundra Experiment (ITEX). Global Change Biology, 3(S1), 1-9. https://doi.org/10.1111/j.1365-2486.1997.gcb132.x

Hobbie, S. E., \& Chapin, F. S. (1998). The response of tundra plant biomass, aboveground production, nitrogen, and $\mathrm{CO}_{2}$ flux to experimental warming. Ecology, 79(5), 1526-1544. https://doi.org/10.1890/0012-9658(1998)079\%5B1526:TROTPB\%5D2.0.CO;2

Hollesen, J., Buchwal, A., Rachlewicz, G., Hansen, B. U., Hansen, M. O., Stecher, O., \& Elberling, B. (2015). Winter warming as an important co-driver for Betula nana growth in western Greenland during the past century. Global Change Biology, 21(6), 2410-2423. https://doi.org/ $10.1111 / \mathrm{gcb} .12913$

Holst, T., Arneth, A., Hayward, S., Ekberg, A., Mastepanov, M., Jackowicz-Korczynski, M., ... Bäckstrand, K. (2010). BVOC ecosystem flux measurements at a high latitude wetland site. Atmospheric Chemistry and Physics, 10(4), 1617-1634. https://doi.org/10.5194/ acp-10-1617-2010

Huber, S. G., Wunderlich, S., Schöler, H. F., \& Williams, J. (2010). Natural abiotic formation of furans in Soil. Environmental Science \& Technology, 44(15), 5799-5804. https://doi.org/10.1021/es100704g

IPCC (2013). Climate change 2013: The physical science basis, Contribution of working group I to the fifth assessment report of the intergovernmental panel on climate change (pp. 9-10). United Kingdom and New York: Cambridge University Press.

Jonasson, S. (1988). Evaluation of the point intercept method for the estimation of plant biomass. Oikos, 52(1), 101-106.

Kesselmeier, J., \& Staudt, M. (1999). Biogenic volatile organic compounds (VOC): An overview on emission, physiology and ecology. Journal of Atmospheric Chemistry, 33(1), 23-88. https://doi.org/10.1023/a:1006127516791

Kramshøj, M., Vedel-Petersen, l., Schollert, M., Rinnan, A., Nymand, J., Ro-Poulsen, H., \& Rinnan, R. (2016). Large increases in Arctic biogenic volatile emissions are a direct effect of warming. Nature Geoscience, 9(5), 349-352. https://doi.org/10.1038/ngeo2692

Kulmala, M., Suni, T., Lehtinen, K. E. J., Dal Maso, M., Boy, M., Reissell, A., ... Hari, P. (2004). A new feedback mechanism linking forests, aerosols, and climate. Atmospheric Chemistry and Physics, 4(2), 557-562. https://doi.org/10.5194/acp-4-557-2004 
Laothawornkitkul, J., Taylor, J. E., Paul, N. D., \& Hewitt, C. N. (2009). Biogenic volatile organic compounds in the Earth system. New Phytologist, 183(1), 27-51. https://doi.org/10.1111/j.1469-8137.2009.02859.x

Leff, J. W., \& Fierer, N. (2008). Volatile organic compound (VOC) emissions from soil and litter samples. Soil Biology and Biochemistry, 40(7), 1629-1636. https://doi.org/10.1016/j.soilbio.2008.01.018

Lindwall, F., Faubert, P., \& Rinnan, R. (2015). Diel variation of biogenic volatile organic compound emissions- A field study in the sub, low and high Arctic on the effect of temperature and Light. PLOS ONE, 10(4), e0123610. https://doi.org/10.1371/journal.pone.0123610

Lindwall, F., Schollert, M., Michelsen, A., Blok, D., \& Rinnan, R. (2016). Fourfold higher tundra volatile emissions due to Arctic summer warming. Journal of Geophysical Research: Biogeosciences, 121, 895-902. https://doi.org/10.1002/2015JG003295

Lindwall, F., Svendsen, S. S., Nielsen, C. S., Michelsen, A., \& Rinnan, R. (2016). Warming increases isoprene emissions from an Arctic fen Science of the Total Environment, 553, 297-304. https://doi.org/10.1016/j.scitotenv.2016.02.111

Loreto, F., \& Schnitzler, J.-P. (2010). Abiotic stresses and induced BVOCs. Trends in Plant Science, 15(3), 154-166. https://doi.org/10.1016/ j.tplants.2009.12.006

Marchand, F. L., Nijs, l., de Boeck, H. J., Kockelbergh, F., Mertens, S., \& Beyens, L. (2004). Increased turnover but little change in the carbon balance of high-Arctic tundra exposed to whole growing season warming. Arctic, Antarctic, and Alpine Research, 36(3), $298-307$.

Niinemets, Ü., Arneth, A., Kuhn, U., Monson, R. K., Peñuelas, J., \& Staudt, M. (2010). The emission factor of volatile isoprenoids: Stress, acclimation, and developmental responses. Biogeosciences, 7(7), 2203-2223. https://doi.org/10.5194/bg-7-2203-2010

Oberbauer, S. F., Tweedie, C. E., Welker, J. M., Fahnestock, J. T., Henry, G. H. R., Webber, P. J., ... Starr, G. (2007). Tundra $\mathrm{CO}_{2}$ fluxes in response to experimental warming across latitudinal and moisture gradients. Ecological Monographs, 77(2), 221-238. https://doi.org/10.1890/ 06-0649

Oechel, W. C., Vourlitis, G. L., Hastings, S. J., Zulueta, R. C., Hinzman, L., \& Kane, D. (2000). Acclimation of ecosystem $\mathrm{CO}_{2}$ exchange in the Alaskan Arctic in response to decadal climate warming. Nature, 406(6799), 978-981. https://doi.org/10.1038/35023137

Ortega, J., \& Helmig, D. (2008). Approaches for quantifying reactive and low-volatility biogenic organic compound emissions by vegetation enclosure techniques-Part A. Chemosphere, 72(3), 343-364. https://doi.org/10.1016/j.chemosphere.2007.11.020

Paasonen, P., Asmi, A., Petäjä, T., Kajos, M. K., Äijälä, M., Junninen, H., ... Kulmala, M. (2013). Warming-induced increase in aerosol number concentration likely to moderate climate change. Nature Geoscience, 6(6), 438-442. https://doi.org/10.1038/ngeo 1800

Peñuelas, J., Asensio, D., Tholl, D., Wenke, K., Rosenkranz, M., Piechulla, B., \& Schnitzler, J. P. (2014). Biogenic volatile emissions from the soil, Plant. Cell \& Environment, 37(8), 1866-1891. https://doi.org/10.1111/pce.12340

Potosnak, M. J., Baker, B. M., LeStourgeon, L., Disher, S. M., Griffin, K. L., Bret-Harte, M. S., \& Starr, G. (2013). Isoprene emissions from a tundra ecosystem. Biogeosciences, 10(2), 871-889. https://doi.org/10.5194/bg-10-871-2013

Ravn, N. R., Ambus, P., \& Michelsen, A. (2017). Impact of decade-long warming, nutrient addition and shading on emission and carbon isotopic composition of $\mathrm{CO}_{2}$ from two subarctic dwarf shrub heaths. Soil Biology and Biochemistry, 111, 15-24. https://doi.org/10.1016/ j.soilbio.2017.03.016

Rinnan, R., Michelsen, A., \& Jonasson, S. (2008). Effects of litter addition and warming on soil carbon, nutrient pools and microbia communities in a subarctic heath ecosystem. Applied Soil Ecology, 39(3), 271-281. https://doi.org/10.1016/j.apsoil.2007.12.014

Rinnan, R., Rinnan, Å., Holopainen, T., Holopainen, J. K., \& Pasanen, P. (2005). Emission of non-methane volatile organic compounds (VOCs) from boreal peatland microcosms-Effects of ozone exposure. Atmospheric Environment, 39(5), 921-930. https://doi.org/10.1016/ j.atmosenv.2004.09.076

Rustad, L., Campbell, J., Marion, G., Norby, R., Mitchell, M., Hartley, A., ... Gurevitch, J. (2001). A meta-analysis of the response of soil respiration, net nitrogen mineralization, and aboveground plant growth to experimental ecosystem warming. Oecologia, 126(4), 543-562. https://doi.org/10.1007/s004420000544

Schollert, M., Burchard, S., Faubert, P., Michelsen, A., \& Rinnan, R. (2014). Biogenic volatile organic compound emissions in four vegetation types in high Arctic Greenland. Polar Biology, 37(2), 237-249. https://doi.org/10.1007/s00300-013-1427-0

Schollert, M., Kivimäenpää, M., Valolahti, H. M., \& Rinnan, R. (2015). Climate change alters leaf anatomy, but has no effects on volatile emissions from Arctic plants, plant. Cell \& Environment, 38(10), 2048-2060. https://doi.org/10.1111/pce.12530

Scott, C. E., Rap, A., Spracklen, D. V., Forster, P. M., Carslaw, K. S., Mann, G. W., ... Tunved, P. (2014). The direct and indirect radiative effects of biogenic secondary organic aerosol. Atmospheric Chemistry and Physics, 14(1), 447-470. https://doi.org/10.5194/acp-14-447-2014

Sharkey, T. D., Singsaas, E. L., Lerdau, M. T., \& Geron, C. D. (1999). Weather effects on isoprene emission capacity and applications in emissions algorithms. Ecological Applications, 9(4), 1132-1137. https://doi.org/10.2307/2641383

Sharkey, T. D., \& Yeh, S. (2001). Isoprene emission from plants. Annual Review of Plant Physiology and Plant Molecular Biology, 52(1), $407-436$. https://doi.org/10.1146/annurev.arplant.52.1.407

Sindelarova, K., Granier, C., Bouarar, I., Guenther, A., Tilmes, S., Stavrakou, T., ... Knorr, W. (2014). Global data set of biogenic VOC emissions calculated by the MEGAN model over the last 30 years. Atmospheric Chemistry and Physics, 14(17), 9317-9341. https://doi.org/10.5194/ acp-14-9317-2014

Sistla, S. A., Moore, J. C., Simpson, R. T., Gough, L., Shaver, G. R., \& Schimel, J. P. (2013). Long-term warming restructures Arctic tundra without changing net soil carbon storage. Nature, 497(7451), 615-618. https://doi.org/10.1038/nature12129

Slot, M., \& Kitajima, K. (2015). General patterns of acclimation of leaf respiration to elevated temperatures across biomes and plant types. Oecologia, 177(3), 885-900. https://doi.org/10.1007/s00442-014-3159-4

Staudt, M., \& Bertin, N. (1998). Light and temperature dependence of the emission of cyclic and acyclic monoterpenes from holm oak (Quercus ilex L.) leaves. Plant, Cell \& Environment, 21(4), 385-395. https://doi.org/10.1046/j.1365-3040.1998.00288.x

Tang, J., Schurgers, G., Valolahti, H., Faubert, P., Tiiva, P., Michelsen, A., \& Rinnan, R. (2016). Challenges in modeling isoprene and monoterpene emission dynamics of Arctic plants: A case study from a subarctic tundra heath. Biogeosciences, $13(24), 6651-6667$. https://doi.org/10.5194/bg-13-6651-2016

Tiiva, P., Faubert, P., Michelsen, A., Holopainen, T., Holopainen, J. K., \& Rinnan, R. (2008). Climatic warming increases isoprene emission from a subarctic heath. New Phytologist, 180(4), 853-863. https://doi.org/10.1111/j.1469-8137.2008.02587.x

Truong, C., Palme, A. E., \& Felber, F. (2007). Recent invasion of the mountain birch Betula pubescens ssp. tortuosa above the treeline due to climate change: Genetic and ecological study in northern Sweden. Journal of Evolutionary Biology, 20(1), 369-380. https://doi.org/10.1111/ j.1420-9101.2006.01190.x

Valolahti, H., Kivimäenpää, M., Faubert, P., Michelsen, A., \& Rinnan, R. (2015). Climate change-induced vegetation change as a driver of increased subarctic biogenic volatile organic compound emissions. Global Change Biology, 21(9), 3478-3488. https://doi.org/10.1111/ gcb.12953

Vedel-Petersen, I., Schollert, M., Nymand, J., \& Rinnan, R. (2015). Volatile organic compound emission profiles of four common Arctic plants. Atmospheric Environment, 120, 117-126. https://doi.org/10.1016/j.atmosenv.2015.08.082 
Wahren, C. H. A., Walker, M. D., \& Bret-Harte, M. S. (2005). Vegetation responses in Alaskan Arctic tundra after 8 years of a summer warming and winter snow manipulation experiment. Global Change Biology, 11(4), 537-552. https://doi.org/10.1111/j.1365-2486.2005.00927.x

Walker, M. D., Wahren, H. C., Hollister, R. D., Henry, G. H. R., Ahlquist, L. E., Alatalo, J. M., ... Wookey, P. A. (2006). Plant community responses to experimental warming across the tundra biome. Proceedings of the National Academy of Sciences of the United States of America, 103(5), 1342-1346. https://doi.org/10.1073/pnas.0503198103

Welker, J. M., Fahnestock, J. T., Henry, G. H. R., O'Dea, K. W., \& Chimner, R. A. (2004). $\mathrm{CO}_{2}$ exchange in three Canadian High Arctic ecosystems: Response to long-term experimental warming. Global Change Biology, 10(12), 1981-1995. https://doi.org/10.1111/ j.1365-2486.2004.00857.x 